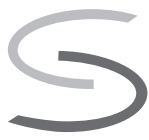

KATARZYNA KABACIŃSKA-LUCZAK ${ }^{1}$

Uniwersytet im. Adama Mickiewicza w Poznaniu

ORCID 0000-0001-8098-3403

\title{
EDUCATION AND UPBRINGING IN THE PAGES OF "WIELKOPOLANIN" (1848-1850)
}

\section{Sprawy oświaty i wychowania na lamach „Wielkopolanina” (1848-1850) \\ Abstrakt}

Celem artykułu jest próba pokazania „oświecenia” wielkopolskiego chłopa w połowie XIX w. w dedykowanych jemu czasopismach, szczególnie w odniesieniu do spraw oświaty i wychowania. Przedmiotem analizy są informacje dotyczące kwestii edukacyjnych poruszanych na łamach jednego z pism dla ludu - „Wielkopolanina”, który ukazywał w latach 18481850. Wśród podejmowanych zagadnień oświatowych i wychowawczych najważniejszym było krzewienie tożsamości narodowej zarówno w szkole, jak i w domu. Ponadto: wpływ nauczycieli na działalność patriotyczną (ich postaw, wartości, znaczenia w społeczności lokalnej), działalność ochronek, wsparcie dla sierot.

Słowa kluczowe: „Wielkopolanin” 1848-1850; oświata i wychowanie w Wielkopolsce w połowie XIX wieku; opieka nad dzieckiem w połowie XIX wieku

\begin{abstract}
The aim of the article is to attempt and show the "enlightenment" of the peasants of Greater Poland in the middle of the nineteenth century in the magazines addressed to them, especially in relation to matters of education and upbringing. The subject of the research is the information on educational issues raised in one of the magazines for the people - "Wielkopolanin," which was published in the years 1848-1850. Among the educational issues raised, the most important was the promotion of national identity both at school and at home. Further, it covered such topics as the influence of teachers on patriotic activity (their attitudes, values, importance in the local community), the role of village nursery schools, and support for orphans.
\end{abstract}

Keywords: "Wielkopolanin" 1848-1850; education and upbringing in Greater Poland in the middle of the 19th century; childcare in the middle of the 19th century

Dr hab. w Zakładzie Historii Wychowania na Wydziale Studiów Edukacyjnych UAM. Zainteresowania badawcze: historia zabawek dziecięcych, problemy oświaty i wychowania na łamach wielkopolskiej prasy XIX i początku XX wieku. Sekretarz czasopisma „Studia Edukacyjne”. E-mail: kaka@amu.edu.pl. 
$\mathrm{T}$

he 19th century, diversified philosophically, politically, economically, technically, socially, and culturally, had a specific character in Poland. The preservation of national identity under the partitions lay at the core of the activities undertaken. The sense of national distinctiveness was manifested in various ways - from political insurrection, through literature to organic work, including the organisation of education, and the spread of national awareness in the printed media, i.e., the so-called "Polish cultural message." 2

The aim of this study is to present the "enlightenment" of the peasants in Greater Poland in the middle of the nineteenth century in the magazines addressed to them, especially with respect to matters of education and upbringing. The subject of the analysis is the information on educational issues raised in one of the magazines for the peasant readers "Wielkopolanin," which was published in the years 1848-1850. Papers for ordinary people, including the periodical of our interest, have already been studied extensively. Noteworthy are works by Zygmunt Dulczewski and Grażyna Gzella, among others. These researchers focus mainly on the press, social issues, the circulation of the periodical and its impact on the readers. However, the issues of education and upbringing are discussed rather briefly. Although not dominant in the periodical, they were part of its programme assumptions.

The emergence of texts addressed to peasants was possible when the peasant question became politically, economically, and socially important, i.e., in the second half of the 18th century. ${ }^{3}$ However, the full bloom of the publication of periodicals, including those addressed to ordinary people, arrived in the 19th century, when there was a noticeable increase in their quantity and quality. In the Prussian partition this growth took place in the 1840s, and was significantly influenced by the relaxation of censorship, thanks to the Decree of 17 March 1848. By this document, preventive censorship was abolished, and the authorities could take notice of the content of articles only after their publication (repressive censorship). ${ }^{4}$

Obviously, "Wielkopolanin" belongs to local periodicals whose beginnings date back to the second half of the 18th century and its development began with the Duchy of Warsaw. The local press of the Grand Duchy of Posen undoubtedly played an important role in the struggle to maintain the national identity of residents. ${ }^{6}$ In addition, it had other functions, such as information, encouragement and motivation, socialisation, and education as well as advertising and publicity. ${ }^{7}$ It must also be remembered that periodicals for common people did not need to be regional in character. Peasants could subscribe to titles from other regions, and even from other partitions. ${ }^{8}$

\footnotetext{
2 The term by Bohdan Cywiński is given after G. Kucharczyk, Dtugi kulturkampf. Pruskie i niemieckie wojny kulturowe przeciw Polsce w latach 1795-1918, Warszawa 2021, p. 16.

3 G. Gzella, ,Pisma dla ludu” pod zaborami w pierwszej połowie XIX wieku, Torun 2004, p. 31-34.

4 G. Gzella, Pruskie prawo prasowe w drugiej połowie XIX wieku, in: W kregu prasy (przeszłość - teraźniejszość - przyszłość), vol. 2, eds. G. Gzella, J. Gzella, Toruń 2001, p. 33; por. W. Kolasa, Historiografia prasy polskiej (do 1918 roku: naukometryczna analiza dyscypliny 1945-2009), Kraków 2013, p. 163.

5 R. Kowalczyk, Prasa lokalna w Polsce, Poznań 2000, p. 30; see H. Syska, Od „Kmiotka” do ,Zarania”. Z historii prasy ludowej, Warszawa 1949, p. 28.

6 L. Cybulska, Polskie czasopisma literackie w życiu kulturalnym Polaków Wielkiego Księstwa Poznańskiego w XIX wieku, in: W kregu prasy (przeszłość - teraźniejszość - przyszłość), vol. 2, eds. G. Gzella, J. Gzella, Toruń 2001, p. 8.

$7 \quad$ R. Kowalczyk, Prasa lokalna w Polsce, op. cit., p. 20.

8 G. Gzella, „Pisma dla ludu” pod zaborami, op. cit., p. 56; e.g. Warsaw’s „Kmiotek”, Galicia’s „,Wieśniak”, etc.
} 
The emergence of periodicals that consciously addressed peasants in the Grand Duchy of Posen required appropriate conditions in both macro- and micro-social/political contexts. The former included the formation and dynamic development of new types of press in the Polish lands, e.g., political press, illustration magazines, and folk press. ${ }^{9}$ The latter flourished mainly in the Prussian partition and Galicia. ${ }^{10}$

As to the micro aspect, the following should be noted: the altering socio-political situation after Friedrich Wilhelm IV ascended to the throne in Berlin (easing of the anti-Polish course), ${ }^{11}$ changes taking place in the countryside (development of rural education, ${ }^{12}$ the struggle against illiteracy, the higher position of the peasantry in the Grand Duchy of Posen compared to other partitions, the ongoing process of enfranchisement of the peasantry and the stratification of rural areas, the increased importance of the peasantry in public life, especially after the Greater Poland Uprising) ${ }^{13}$ the awakening of the public during the "golden age of Poznan culture" (1834-1848), ${ }^{14}$ and the changes that occurred after $1848 .{ }^{15}$ Important is that "the peasants in Greater Poland, thanks to elementary schools, had some preparation for independent reading and writing and at the same time were the most nationally aware". ${ }^{16}$ The year 1848 can be regarded as a turning point, when, among the achievements of the "March events" next to the introduction of certain concessions such as universal suffrage in Prussia and freedom of association, freedom of the press was also introduced, thus abolishing censorship. ${ }^{17}$ In addition, "the editorial board of Gazeta Polska, published in Poznań in July 1848, supported an appeal addressed to the clergy of the Grand Duchy of Posen calling on the clergy to publish a magazine for the country folk."18 This request emphasised the fact that peasants, especially the young, were becoming increasingly literate. ${ }^{19}$ It also pointed out the features a magazine for common people should possess, such as: the level of writing adapted to the reader, consisting of 2 parts - national (references to the past, present, and future of Poles) and political (events in Europe, rights and duties of a citizen, the structure of the government, etc.). ${ }^{20}$ The editors of the periodicals for ordinary people "believed that familiarising peasants with events taking place outside their villages, explaining the meaning

\footnotetext{
9 W. Kolasa, op. cit., p. 165.

10 Ibidem.

11 L. Trzeciakowski, Pod pruskim zaborem 1850-1918, Warszawa 1973, p. 21.

12 "As early as the middle of the 19th century, compulsory education covered about $85 \%$ of children. Thanks to this, illiteracy ceased to be a mass phenomenon. Folk education was based on the principle of religion and was divided into: Catholic, Evangelical and Jewish”, ibidem, p. 17; also found in. G. Gzella, ,,Pisma dla ludu” pod zaborami, op. cit., p. 26.

13 H. Syska, op. cit., p. 148 L. Trzeciakowski, op. cit., p. 15. G. Gzella, Księdza Aleksego Prusinowskiego twórczość dla ludu, http://www.naszaprzeszlosc.pl/files/tom087_09.pdf (Accessed by: 15.04.2021).

14 L. Cybulska, op. cit., p. 19.

15 Por. K. Banaszewski, Rewolucja, powstanie, początek niepodległości czy niepotrzebny zryw? - poglądy polskich uczestników i obserwatorów wokót poznańskiej Wiosny Ludów, „Studia nad Historią, Kulturą i Polityką”, 2007, vol. 1.

16 G. Gzella, Czytelnictwo „pism dla ludu” w pierwszej połowie XIX wieku, „Acta Universitatis Nicolai Copernici”, 1996, no. 306, p. 167.

17 Z. Dulczewski, Z dziejów prasy ludowej w Wielkim Księstwie Poznańskim 1848-1850, Warszawa 1957, p. $22-$

-23; G. Gzella, Pruskie prawo prasowe, op. cit., p. 33-34; W. Kolasa, op. cit., p. 163; H. Syska, op. cit., p. 67.

18 G. Gzella, ,Pisma dla ludu” pod zaborami w pierwszej połowie XIX wieku, Toruń 2004, p. 40.

19 Inter alia, the "law in relation to the press" of 17 March 1848; the new press law 30.06.1849.

20 „Gazeta Polska”, 1848, no. 97, after: G. Gzella, „Pisma dla ludu” pod zaborami, op. cit., p. 40-41.
} 
of the social, political and civilisational changes taking place at that time in an accessible - and, at the same time, appropriately oriented - way, would give the peasants a chance to 'become citizens,' thus mitigating conflicts in rural areas." 21 The issue of spreading education and readership among peasants in the Grand Duchy of Posen and West Prussia was taken up by the Polish League established in Berlin in June 1848, which, apart from its crossclass character, emphasised organic work and popularised the slogan of social solidarity. ${ }^{22}$ It also took over the care for the "people's magazines" ${ }^{23}$ which was handled by one of its five departments for publications and national education. ${ }^{24}$ In the Grand Duchy of Posen magazines addressed to peasants were published from the 1830s. The most notable were: "Szkółka Niedzielna" ("Sunday School”) (1837-1853) ${ }^{25}$ and "Pismo dla Ludu Polskiego" ("Magazine for the Polish People") (1845). ${ }^{26}$

All the above requirements and conditions were met by „Wielkopolanin”, published from 4 October 1848. "Wielkopolanin" was a periodical independent of the Prussian authorities, dealing with current political issues. The paper was issued twice a week, on Wednesdays and Saturdays, from 4.10.1848 to 29.06.1950. The paper's founder and first editor was Rev. Aleksy Prusinowski, ${ }^{27}$ and from 3.10.1849, nominally, Walenty Stefański, ${ }^{28}$ probably together with Ewaryst Estkowski. ${ }^{29}$ W. Stefański ${ }^{30}$ was its publisher and printer. The magazine had a book format (23.5x17.5), a rather large, uniform font and a clear, two-page layout. The first part of each issue included political and/or social articles, the second - the so-called news. The circulation of the periodical in the first quarter amounted to 1349 subscribers, in the second - 1511. "It "It was the highest number of subscribers among those achieved by Polish magazines at that time." 32 It seems, however, that there were more recipients as the magazine was read at meetings of the Polish League or folk gatherings during which a teacher or manor's owner would introduce the topic of the issue ${ }^{33}$ as well as at evening home meetings. ${ }^{34}$

The Directorate of the League instructed the local branches to read "Wielkopolanin" at meetings, which was supposed to contribute to increasing the number of readers, especially

\footnotetext{
21 G. Gzella, ,Pisma dla ludu” pod zaborami, op. cit., p. 94.

22 L. Trzeciakowski, op. cit., p. 32-33; The Polish League was dissolved on April 8, 1850.

23 Cf. L. Trzeciakowski, op. cit., p. 35-36.

24 G. Gzella, Księdza Aleksego Prusinowskiego twórczość dla ludu, op. cit., p. 270.

25 L. Trzeciakowski, op. cit., p. 36.

26 A. Koziołek, Działalność rynku polskiej prasy ludowej dla środowisk wiejskich w zaborze pruskim, „Wieś i Rolnictwo", 2019, no. 2, p. 137; see Prasa polska w latach 1661-1864, red. J. Łojek, Warszawa 1976, p. 247.

27 G. Gzella, Księdza Aleksego Prusinowskiego twórczość dla ludu, op. cit., p. 273.

28 G. Gzella, „Przed wysokim sądem” Procesy prasowe polskich redaktorów czasopism dla chłopów w zaborze pruskim, Torun 2004, p. 107.

29 Prusinowski's resignation from the editorial post was probably due to a conflict between him and Stefanski, see

Z. Dulczewski, Z dziejów prasy ludowej, op. cit., p. 56. G. Gzella, „Przed wysokim sądem”, op. cit., p. 105.

30 The transfer of printing to Kościan resulted from the law of 13 September 1849 prohibiting the publication of the paper until the state of siege was lifted; in. Z. Dulczewski, Z dziejów prasy ludowej, op. cit., p. 54.

31 Z. Dulczewski, op. cit., p. 131; por. L. Trzeciakowski, op. cit., p. 36.

32 Z. Dulczewski, op. cit., p. 39.

33 Prasa polska w latach 1661-1864, op. cit., p. 256.

34 G. Gzella, Czytelnictwo ,pism dla ludu”, op. cit., p. 153-154.
} 
among illiterate people. ${ }^{35}$ And indeed, there are sources confirming these recommendations. ${ }^{36}$ It is important that "Wielkopolanin" was also read by peasants themselves, which may serve as evidence of emerging reading needs among this social stratum. ${ }^{37}$ It should also be noted that the magazine reached readers not only in the Grand Duchy of Posen but also in West Prussia, Silesia, and the Kingdom of Poland..$^{38}$

The aim of the paper was to "enlighten" the rural population. It promoted the idea of social solidarity, ${ }^{39}$ appealed to priests, landlords, and teachers to work together to regain independence. ${ }^{40}$ The presentation of the principles of social solidarity was intended to convince readers of the "necessity of preserving existing social arrangements. ${ }^{.41}$ Already in the $1^{\text {st }}$ issue the editor declared, "And we will write to you how to send your children to school and how you yourselves in the Church of God should worship the Lord. And how your children will learn in the Polish school what they need, how in the Church of God we will ask for Poland, how we will strive for the Polish virtues of our ancestors, for hospitality at home, for work in the fields, for valour in battle, for wealth on the farm, and I ask you, where in the world is there a man who will not admit that we are Poles?"42 The promotion of interaction of peasants with the nobility resonated with the programme of "freedom," which could be regained through prayer. ${ }^{43}$ According to researchers, Fr. A. Prusinowski "imposed a religious interpretation of the national history and life" ${ }^{" 44}$ and his concept of nationhood based on religion, land, and language was raised many times on the pages of the journal.

In addition to shaping attitudes to the country's past by publishing information about historical figures (e.g., Tadeusz Kościuszko, Józef Poniatowski, Jan Henryk Dąbrowski) and important events (e.g., the Kościuszko Uprising), current political information was also provided (e.g., the obligation to vote for Polish candidates during elections, the uprising in Hungary), a campaign was conducted to keep the land in the hands of Poles, and foreign news was printed (e.g., about the situation in the partitions). From the beginning of its circulation, "Wielkopolanin" was exposed to repressions ${ }^{45}$ After the introduction of the new press law on 30 June 1849, "Wielkopolanin" was often subject to repressive censorship. ${ }^{46}$

\footnotetext{
35 Z. Dulczewski, op. cit., p. 40; por. Gzella, Czytelnictwo „pism dla ludu”, op. cit., p. 154.

36 G. Gzella, Czytelnictwo „pism dla ludu”, op. cit., p. 159.

37 Ibidem, p. 159. "When the president of the Poznan province issued a ban on reading the magazine at the League meetings, all members of the organization in Gniezno subscribed to the magazine individually," ibidem, p. 160.

38 Ibidem, p. 159.

39 R. Kowalczyk, Prasa lokalna $w$ Polsce, op. cit., p. 47. The solidaristic views were most fully presented by "Wielkopolanin," which proclaimed the slogan of harmony between Poles, according to the principle "harmony builds, disagreement ruins” (1848, no. 6). G. Gzella, „Pisma dla ludu” pod zaborami, op. cit., p. 113-114; I. Turowska-Bar, Polskie czasopisma o wsi i dla wsi, Warszawa 1963, p. 25.

40 "Passing through Promno, a village near Pobiedziska, I stopped in to see the teacher, to learn from him about the good intentions and benefits of the local peasants that they derive from reading "Wielkopolanin'" (1849, no. 3).

41 G. Gzella, Księdza Aleksego Prusinowskiego twórczość dla ludu, op. cit., p. 272.

42 „Wielkopolanin”, 1848, no. 1.

43 Prasa polska w latach 1661-1864, op. cit., p. 255.

44 Ibidem.

45 G. Gzella, „Przed wysokim sądem”, op. cit., p. 99 .

46 Por. Z. Dulczewski, op. cit., p. 53; The abolition of certain press privileges in 1848 resulted in the introduction of new restrictions in 1849 , including the requirement to include the name and address of the printer, distributor, and publisher, as they became the persons held liable in the event of inappropriate content printed in a given periodical.
} 
Several issues were seized and confiscated.$^{47}$ According to Z. Dulczewski, "Wielkopolanin" was under special surveillance and observation by the Poznań prosecutor's office. The Prussians were disturbed by the tactics of the magazine, which pointed at the Prussians as the perpetrator of all misfortunes in the countryside while "whitewashing" the Polish nobility. ${ }^{48}$ The result was not only a halt in printing but also lawsuits against the magazine and its editor, Rev. A. Prusinowski. A year later, a new press ordinance of 5 June 1850 introduced, a.o., restrictions on distribution, high cash deposits, refusal of postal debits, etc., for most Polish periodicals. ${ }^{49}$ This law was supposed to limit the influence of Polish magazines on the Polish population and, subsequently, to close them. ${ }^{50}$ The press regulation contributed to the discontinuation of "Wielkopolanin."

The topics of education and upbringing were not the dominant problems addressed in "Wielkopolanin." "For almost two years, relatively few articles dealing with educational issues were published, which shows that it had ambitions to be a political and informational magazine." ${ }^{51}$. Among the subjects addressed in the field of education and upbringing, which were meant to promote the national identity, attention should be drawn to the importance and role of school in the upbringing of generations of Poles, and the influence of teachers on patriotic activities (their attitudes, values, importance in the local community). Moreover, referring to the organic work, there were appeals for support of orphans and for establishing orphanages as well as calls for reading books and magazines by peasants. Reading, so it was proclaimed, was no longer a matter of the priest, teacher, and landowner only.

Knowing that the editor Rev. A. Prusinowski perceived all misfortunes in Greater Poland countryside as a consequence of the occupant's actions, and that he thought Poland should be united by three most important elements: religion, land, and language, it is not surprising that already in the first issue of 1848 he expresses his opposition to the separation of school from ecclesiastical supervision. He considers this postulate inappropriate, "because children in such schools might miss the most important teaching, that is catechism, the sacred history." ${ }^{2}$ He also notes that once the school supervision is taken away from priests, German teachers, who do not know the Polish language, may be employed in schools. Prusinowski urges his readers to sign a petition to maintain the present forms of supervision. It is also noteworthy that the editor appeals for the creation of a community between the priest, teacher, and peasant. The cited example of a struggle for the "Polish" school associated with the church and the nobility not only testifies to the spread of patriotic attitudes in favour of preserving the language as a substitute for Polishness, but it also resulted from a certain broader policy of periodicals in the first half of the 19th century. According to Grażyna Gzella, "Formally, a peasant received land from the hands of the monarch, which tied him to the occupying

\footnotetext{
In addition, a paragraph on offence against majesty (of the King and Queen) was introduced, G. Gzella, Pruskie prawo prasowe, op. cit., p. 35.

47 Among others 1849 , nos. 69, 95, 99; 1850, no. 18, 34, 35, 38, 39.

48 Z. Dulczewski, op. cit., p. 54.

49 Ibidem, p. 73; see L. Trzeciakowski, op. cit., p. 36.

50 L. Trzeciakowski, op. cit., p. 37.

51 G. Gzella, ,Pisma dla ludu” pod zaborami, op. cit., p. 147.

52 1848, no. 1, According to Arthur Jazdon's findings, "between mid-October 1849 and June 1850, a total of twelve issues of 'Wielkopolanin' out of sixty-four published were questioned and taken away” after: G. Gzella „,Przed wysokim sądem”, op. cit., p. 107.
} 
authorities and distanced from the aspirations for independence. For this reason, the editors of [...] magazines convinced peasants so strongly about the extraordinary role of the nobility in the political events of the 1840 s, especially in social issues, and tried to link the peasant issue with the idea of an independent Poland." ${ }^{53}$

According to Prusinowski, "Education, virtue and honesty stem from the Catholic religion, this nation can only be happy where there is education, virtue and honesty." ${ }^{\circ 4}$ Education is to protect patriotic and Polish values. Repeatedly, the editor of "Wielkopolanin" warns against "being duped by vagabonds," who cause confusion in social relations of villagers. ${ }^{55}$ Consistently, throughout the period of the paper's publication, all educational measures that could negatively affect the school were criticised. In 1849, the Berlin News wrote, "They report to us that the Sejm has decreed that schools are now to be free and the government is to pay a teacher; and this would be good, but now the government will also have the sole supervision over the teacher, and the school will depend on the government and not on the municipality. This is very bad, and it will be to our great detriment." ${ }^{96}$ The educational changes concerning the prohibition of boys not living in Poznan to attend the Polish gymnasium were reported with sadness, "all boys from the surrounding villages and towns will be removed." ${ }^{57}$ On several occasions the editors commented negatively on the fact that there were more and more German teachers in Poznan schools, which had a negative effect on boys' education. ${ }^{58}$ The pledges of 1815 concerning national schools and the maintenance of Polish nationality were recalled. ${ }^{59}$ Reorganisation of education for priests was negatively commented on as well. ${ }^{60}$ There were repeated calls for a Polish school with a Polish teacher for Polish children. ${ }^{61}$ Examples were given of the activities of the Scientific Aid Society in Chelmno, "And so a peasant's son and a poor labourer's boy sit next to a nobleman's boy on one bench at school, and better is the one who does better at school, because there is equality, as God has commanded." ${ }^{62}$

There was frequent emphasis on the "most sacred and civic" duty to educate children at school, "this is what even the fatherland expects of everyone, that they send their children to school." ${ }^{63}$ They appealed not to keep children at home, "Let us remember that education is the source of all prosperity in the nation! Let us not deplete it for the children through our negligence or overemployment of children at home." ${ }^{94}$ Therefore, education was associated

${ }_{53}$ G. Gzella, ,Pisma dla ludu” w I połowie XIX w. jako źródto do badan nad ksztaltowaniem świadomości czytelnika wiejskiego, „Acta Universitas Lodziensis”, 1992, no. 46, p. 126.

${ }_{54}$ Co potrzeba do szczęścia narodu?, "Wielkopolanin", 1849, no. 10, p. 38-39.

55 Ibidem, p. 39.

56 Nowiny z Berlina, "Wielkopolanin", 1849, no. 102, p. 112.

57 Nowiny z Poznania, "Wielkopolanin", 1850, no. 51, p. 231.

58 Doniesienie od Sejmu, "Wielkopolanin", 1849, no. 75, p. 298; Nowiny z Poznania, "Wielkopolanin", 1850, no. 43, p. 199.

59 Nowiny z Poznania, "Wielkopolanin", 1850, no. 51, p. 231-232.

60 O wolności Kościoła, "Wielkopolanin", 1849, no. 12, p. 45-46.

61 "There were only 790 village schools in the Poznań region [...] in 1816, 884 teachers, and 31,000 school-going children. Today, there are 200000 children in rural schools, taught by 2044 teachers in 1885 schools", "Wielkopolanin", 1850, no. 23.

62 O Prusach zachodnich, "Wielkopolanin", 1849, no. 89, p. 354.

${ }_{63}$ List żatosny do Wielkopolanina o szkole, "Wielkopolanin", 1849, no. 54, p. 215.

64 Ibidem. 
not only with individual education but also with benefits for the nation, notably "since reading is so essential to every human being, we should study and send our children to school, lest the Germans always point at us that we are ignorant." 65

In "Wielkopolanin" school issues were closely connected with respect for the Polish language. On the one hand, Father A. Prusinowski often made his readers aware of the lack of respect for the Polish language by the occupant, writing, a.o., that "in many Polish schools there are German teachers, and many Polish schools have already changed forever to German." ${ }^{\prime 66}$ On the other hand, he emotionally urged the readers, saying, "No one else but your mummy and daddy taught you to speak Polish. And who taught you to read and write? Your teachers in the villages and towns where you went to school. So, believe them, after the noblemen and priests, who taught you to read and write in Polish. [...] For all Poles love their language as much as a mother loves the child she carried in her heart! So, loving our Polish language, we should love those who teach us to speak Polish - we should believe them too." ${ }^{67}$

"Wielkopolanin" often published news for teachers and about teachers. It informed about vacancies and competitions for teaching positions, activities of societies as well as aid for teachers. All these issues were strictly connected with the educational, pedagogical, and patriotic activity of teachers. This shows that "Wielkopolanin" intended to influence rural teachers, whose role in promoting national solidarity it repeatedly emphasised. The teacher's work was perceived not only as an educational but also a religious and patriotic activity. "A good teacher is one who brings up nice children, teaches them the rosary and fear of God, dissuades young people from evil, and leads them to virtue and all good things." ${ }^{\prime \prime}$

Vacancy advertisements often appeared in the periodical, stating the place of employment, requirements for the teacher, the salary, and housing conditions. "The Board of Trustees of the Catholic School at Środa calls for the vacant position of the first teacher, a Pole, of the Catholic religion, so disposed that he could at least prepare young people for [...] junior high schools. The salary is 250 thalers, the accommodation is free and there is a garden." ${ }^{69}$ In submitting documents, the applicant had to include certificates of good conduct and abilities.

Advertisements of competition for the post of teacher were also issued. As an example, let us take the following advertisement: "Due to the death of Antoni Mrówczyński, the position of the first teacher at the local Catholic school has become vacant. To present the government with a suitable candidate for this position, the undersigned School Council announces a public competition for the 25 th of June this year at 8 o'clock in the morning and calls on all teachers who are capable and willing to apply for the said post to come forward on the appointed day [...] and prove their teaching skills by a test which is to take place at the school." 70

The pages of "Wielkopolanin" also spread information about help for teachers. For example, there was an advertisement, "If you know a teacher who lost his office due to the recent riots and is poor, tell him to report to the Main Directorate of the League in Poznań,

\footnotetext{
65 Ibidem.

${ }^{66}$ Jakie będą obowiązki polskich deputowanych na sejmie pruskim?, "Wielkopolanin”, 1849, no. 7, p. 26.

${ }^{67}$ Kogo się trzymać?, "Wielkopolanin", 1848, no. 16, p. 61-62.

68 Zacność stanu wiejskiego, "Wielkopolanin”, 1850, no. 33, p. 153.

69 "Wielkopolanin", 1849, no. 28, p. 112; the advert appeared several times in issues: $34,35$.

70 Obwieszczenie, "Wielkopolanin", 1849, no. 45, p. 180; advertisement also in issues: 48 i 49.
} 
which has three hundred thalers to give to such poor people." 71 There was also information on teachers' careers, for instance, in Mosina "the townspeople were voting for a mayor and elected the teacher who had taught at school there for 18 years." 72

In 1848, the Polish Pedagogical Society (PTP) was founded in Poznan. "One of its main aims was, a.o., to develop its own educational methods, establish public libraries, furnish village schools, etc." ${ }^{\prime 73}$ The Society opposed German pedagogy and referred to the patterns worked out by the Commission of National Education. On the pages of "Wielkopolanin" Rev. A. Prusinowski informed teachers about the activities of the Pedagogical Society since he was a member of its editorial committee, and also published pedagogical articles in "Szkola Polska," 74 which was a journal of the PTP. Moreover, he encouraged teachers and priests to form branches of the society in their towns or villages. "Everyone probably knows that for some time now, in Poznań and many other places, teachers and fathers of families as well as priests living close to each other, have been meeting every fortnight to discuss how Polish children should be brought up in rural and urban schools. This is a very good and praiseworthy thing, so why shouldn't you, dear teacher or priest, who is reading this now, think about a similar Society and how to establish one in your area?"75 It was proudly announced that branches of the pedagogical society were established, e.g., in the district of Szamotuły. "On 12th September this year, at 10 o'clock, there will be the first general meeting of the Polish Pedagogical Society of Szamotuły district [...] to which the supporters of the said society, on its behalf, are kindly invited. Rev. Taszarski, parish priest acting as chairman." " Information was also given on the dates of meetings of the pedagogical society. ${ }^{77}$

In addition, teachers, school janitors, and parish leagues were encouraged to read the new magazines: "Szkola Ludu" ("School for People"), "Szkola Polska" ("Polish School"), ${ }^{79}$ "Szkółki dla Dzieci" ("Schools for Children") - a free supplement addressed to children. ${ }^{80}$ New publications were also advertised, among others, "Teaching Polish Writing and Reading" by Antoni Kiszewski, ${ }^{81}$ or the reissued "Powinności nauczyciela" ("Teacher's Duties") by Grzegorz Piramowicz, which was described as follows, "This work is so important, and it so simply and perfectly indicates the goal of a teacher, the aim of education for ordinary people, and the regulations for bringing up and teaching young people, that even in German pedagogical literature we cannot find an equally good book." 82

\footnotetext{
71 Nowiny z Poznania, „Wielkopolanin”, 1850, no. 20, p. 88.

72 Nowina szósta, "Wielkopolanin”, 1849, no. 64, p. 256.

73 H. Syska, op. cit., p. 88-89.

74 Z. Dulczewski, op. cit., p. 40.

75 Do Nauczycieli, "Wielkopolanin", 1849, no. 16, p. 64.

76 Obwieszczenie, "Wielkopolanin", 1849, no. 73, p. 288.

77 "The meeting of the pedagogical society will be held on 5th June at 10 o'clock in the morning at Środa, in the building of the Catholic school, to which the honourable clergymen, teachers, and all persons sympathetic to the good cause are invited", "Wielkopolanin", 1850, no. 44, p. 204.

78 Doniesienie dla Nauczycieli, "Wielkopolanin", 1848, no. 26, p. 104.

79 E. Estkowski, Szkoła Polska, "Wielkopolanin", 1850, no. 50, p. 228.

80 E. Estkowski, Ogłoszenie, "Wielkopolanin”, 1850, no. 26, p. 120.

81 Ogłoszenie, "Wielkopolanin", 1849, no. 63, p. 252; the price of the publication and how it was acquired were also stated.

82 Doniesienie, "Wielkopolanin", 1850, no. 36, p. 168.
} 
Moreover, teachers were informed about general meetings, e.g., "On July 9th, this year, at 8 a.m. a general meeting of teachers of Września district will be held here in Miłosław, to which all teachers and all friends of Polish students are kindly invited. [...] Rev. Tułodziecki, on the recommendation of a number of teachers." ${ }^{83}$

An important topic taken up on the pages of "Wielkopolanin" were matters relating to orphans and the establishment of homes for them as well as the functioning of shelters for children. This information was published to obtain help for children whose families suffered from fires, floods as well as from fatal diseases (e.g., cholera). ${ }^{84}$ There were appeals for fundraising and aid initiatives were announced: "There are a lot of poor orphans left after these people [who died of cholera - author's note.]; so merciful people brought these children together so that they would not be completely wasted, and they would accommodate these children in one house, where the nuns would bring up these children up for the glory of God and for the benefit of the people." ${ }^{85}$ On several other occasions, the magazine published detailed information about the help given to Poznań orphans. In one of them, the editors reported on the development of the former building of the Oratorian Fathers monastery in Śródka as a place for the care of orphans, which was undertaken by the Daughters of Charity. The generosity of Polish citizens was emphasised, thanks to which clothes and food were purchased for 80 children. The editorial, in line with its aims, pointed out the purpose of bringing up orphans who "study at one time, play at another, and always in harmony and love, and we expect that one day they will grow up for the glory of God and the happiness of people." ${ }^{\prime 86}$ Further issues also reported on the change of the institution's status, which from 1850 onwards admitted children without any limitation as to illness or place of residence. ${ }^{87}$

Prusinowski praised every initiative supporting orphans. He was especially pleased with the donations of children from Rokossewo for flood victims. The children wrote to "Wielkopolanin", "We learned from its writings which we read as well as from our teacher, that a great misfortune happened in Poznan due to the flood this year. We are very sorry for these unfortunate brethren of ours and will give them as much help as we can from our pennies we have saved. It is true that it is only very little, but we have no more, as we are not yet able to earn our own money, and we have only what we sometimes receive from our parents." 88

He also devoted a long passage to inform about Apolinary Kątski's charity concert for the poor: "Because with this money many a young and poor boy will grow up for his homeland and then he will support his compatriots." 89 It should be noted that the generosity of noblemen supporting orphans was repeatedly emphasised; however, while proclaiming the idea of solidarity, also peasants were addressed. "If any of you, kind farmers, arrive in Poznań, especially coming from Śródka, spare your time and go and look at these poor orphans, I can guarantee you that you will weep with tears, [...] maybe you, too, with your

\footnotetext{
83 Obwieszczenie, "Wielkopolanin", 1849, no. 49, p. 196.

84 Interestingly, Prusinovsky accused the Muscovites of bringing the contagious cholera, O sierotach w Poznaniu,

"Wielkopolanin", 1849, no. 51, p. 203.

85 Nowina trzecia, "Wielkopolanin", 1849, no. 25, p. 100.

86 O sierotach w Poznaniu, "Wielkopolanin", 1849, no. 51, p. 203.

87 "Wielkopolanin", 1850, no. 40, p. 188.

88 “Wielkopolanin", 1850, no. 26, p. 120.

89 Nowina druga, "Wielkopolanin", 1849, no. 31, p. 122.
} 
penny or some food will support them, and the Lord will reward you." 90 There were reports on activities for orphans outside Poznań, such as a detailed description of the attempts made by the Bukowska, Brodzka and Granowska Leagues to organise support for orphans. Eventually, due to organisational difficulties, it was decided that the money collected would be given to the parents and guardians of the children in a material form - food was purchased, clothes were made, etc. ${ }^{91}$ There was also an appeal for financial support for the orphanage (for girls) founded by Countess Szołdrska in Wolsztyn. ${ }^{22}$

As for supporting orphans, reference was made to the goodwill and heart of donors and to religious connotations. For the editor, helping orphans means not only fulfilling God's law but also influencing a person's nurture "for the comfort of the family and the homeland." 93 He claimed, "I, too, on my part, intercede for the orphans, for they are children of One God, these orphans; whoever welcomes orphans into his home and gives them a spoonful of food and clothes them when naked, it is as if Lord Jesus were fed and given a garment..."94

In "Wielkopolanin" the basic aim of education was to spread patriotism, preserve national identity, and in consequence regain independence. In one of the published poems entitled "A Mother's Wish," a woman, while putting her child to sleep, asks that it grows up beautifully, is guided by virtues in life, works for bread, but above all her wishes for the child are to

Grow in courage,

So that you may avenge

Your country's injuries with your weapon,

And become a famous man. ${ }^{95}$

An important issue discussed in "Wielkopolanin" was the family. A traditional, patriarchal family was pictured. Prusinowski, desiring to influence fathers, described an example of the relationship between a father and his son who finished education at school, "was with soldiers and visited a decent part of the world, maybe he also served in a manor and saw good farms in Turwia at General Chłapowski's estate [...] and returned home, then father sometimes asks him what would be best to sow in Maciej's field; or whether today to rake hay into heaps, and so they decide together." ${ }^{96}$ The promotion of such family relationships was to influence worldview changes in the countryside, to educate and enlighten the peasantry, and consequently to transform agriculture. It was important for fathers to appreciate and adopt the agrarian innovations that their sons learned in schools.

On the pages of the periodical, old Polish customs were recalled in order to maintain the national tradition. One such example is the entry, "In olden times [...] schoolchildren would go round on New Year's Day singing carols and wishing people all sorts of good things: health, happiness, prosperity, and long life; and a few days after New Year's Day the parish priest would also come to the house with the organist and the churchwarden, consecrate

\footnotetext{
90 O sierotach w Poznaniu, "Wielkopolanin", 1849, no. 51, p. 204.

91 Prośba o miłosierdzie nad sierotami, "Wielkopolanin", 1849, no. 52, p. 205-206.

92 O dobroczynności, "Wielkopolanin", 1850, no. 17, p. 75.

93 Prośba o miłosierdzie nad sierotami, "Wielkopolanin”, 1849, no. 52, p. 207.

94 Ibidem.

95 Życzenie matki, "Wielkopolanin", 1850, no. 25, p. 111.

96 Co to znaczy Obywatel?, "Wielkopolanin", 1848, no. 9, p. 33-34.
} 
the four corners of the house, sing songs, and talk to the people." ${ }^{97}$ Custom changes taking place in the countryside were criticised. "Maybe there are some such people as there are not a few fools among them, but apparently pride, or rather greed, has crept in also among you, landowners, once you took the land for your own. Today a farmer spurns to be a cottager's child godfather, is ashamed to go to a cottager's wedding; [...] Today they pay attention only to the wealth; they do not act like our fathers did, do not behave as Poles should behave." 98

The lack of thrift and caution in the farmyard was criticised, especially in relation to accidents involving children. An example of the drowning of a two-year-old child was given: "No one noticed this until the father came back from the field to water his horses and was shocked when he saw the dead body of his child in the drawn-out bucket. Such are the consequences, brothers, when wells are not fenced, and mothers do not watch over their children." 99 The lack of proper supervision of young children, who were crippled or lost their lives in accidents, was repeatedly rebuked. The editors did not blame working parents for this; they rather proposed setting up a day-care centre for children aged 2-6. It was necessary to find a suitable room with a yard and a garden, to "find a woman not too old, who would be known for her affection towards children, to have them under her care and engage them in various games, tell them some stories from the Scripture, teach them to count and calculate some things, show them various pictures [...], and then maybe someone could make a small plough, a ploughshare, a harrow..." ${ }^{100}$ Also in establishing a village nursery school the editors referred to a community spirit; they encouraged peasants, noblemen, and priests to cooperate and set up the institution. The periodical praised the already existing village nursery schools, emphasising the importance of their activities. ${ }^{101}$

To sum up, let us note that "despite the different ideological and political assumptions adopted by the individual press titles in the Prussian partition, the journalism of Greater Poland formed above all a specific sense of national solidarity, the essence of which were common national goals." 102 The creation of this community is also visible in "Wielkopolanin" which had the largest circulation. Its goal - the "enlightenment" of peasants - seemed to be achievable only with strong cooperation between the manor, priests, and peasants, which is why many texts on education also addressed them. Maintaining the existing social arrangements in the countryside, thanks to the triad: religion-land-language, was to be a guarantee of maintaining national identity. Recalling national anniversaries, attitudes of heroes of the past, and above all, the defence of the nationality, were important issues taken up in "Wielkopolanin."

Matters strictly related to education appeared with varying frequency on the pages of the periodical. Nevertheless, reports on the activities of the Polish Pedagogical Society, the Scientific Aid Society in Chełmno, and other educational initiatives were to motivate landowners to promote education. The appeal to respect the compulsory education of peasant children was to contribute to the decrease of illiteracy, and consequently, to the enhancement

97 Nowe latko, "Wielkopolanin", 1849, no. 1, p. 1.

98 Mitujcie się wzajemnie, "Wielkopolanin", 1849, no. 38, p. 149-150.

99 Nowiny z całego świata, "Wielkopolanin", 1850, no. 45, p. 207.

100 Domy ochrony dla matych dziatek, "Wielkopolanin", 1849, no. 54.

101 Uwiadomienie i prośba, "Wielkopolanin", 1849, no. 56, p. 224.

102 R. Kowalczyk, Wielkopolskie czasopiśmiennictwo okresu zaboru pruskiego $w$ walce o tożsamość narodowa i regionalną. Szkice prasoznawczo-politologiczne, Poznań 2018, p. 67. 
of the national consciousness of peasants. Devotion to orphans and young children spread social solidarity and organic work. The themes of upbringing and teaching children raised in "Wielkopolanin" are, therefore, in line with the ideological and programme principles of the magazine.

\section{Bibliography}

Banaszewski K., Rewolucja, powstanie, początek niepodległości czy niepotrzebny zryw? - poglady polskich uczestników i obserwatorów wokót poznańskiej Wiosny Ludów, „Studia nad Historią, Kulturą i Polityką", 2007, vol. 1, p. 53-68.

Cybulska L., Polskie czasopisma literackie w życiu kulturalnym Polaków Wielkiego Księstwa Poznańskiego w XIX wieku, w: W kręgu prasy (przeszłość - teraźniejszość-przyszłość), vol. 2, eds. G. Gzella, J. Gzella, Toruń 2001, p. 7-31.

Dulczewski Z., Z dziejów prasy ludowej w Wielkim Księstwie Poznańskim 1848-1850, Warszawa 1957.

Gzella G., „Pisma dla ludu” pod zaborami w pierwszej połowie XIX wieku, Toruń 2004.

Gzella G., ,,Pisma dla ludu” w I połowie XIX w. jako źródło do badań nad kształtowaniem świadomości czytelnika wiejskiego, „Acta Universitas Lodziensis”, 1992, no. 46, p. 43-56.

Gzella G., „Przed wysokim sądem”. Procesy prasowe polskich redaktorów czasopism dla chtopów w zaborze pruskim, Torun 2004.

Gzella G., Czytelnictwo „pism dla ludu” w pierwszej połowie XIX wieku, „Acta Universitatis Nicolai Copernici", 1996, no. 306, p. 151-168.

Gzella G., Księdza Aleksego Prusinowskiego twórczość dla ludu, http://www.naszaprzeszlosc.p1/files/ tom087_09.pdf(Accessed by: 15.04.2021).

Gzella G., Pruskie prawo prasowe w drugiej połowie XIX wieku, in: W kregu prasy (przeszłość-teraźniejszość - przyszłość), vol. 2, eds. G. Gzella, J. Gzella, Toruń 2001, p. 33-43.

Kolasa W., Historiografia prasy polskiej (do 1918 roku: naukometryczna analiza dyscypliny 19452009), Kraków 2013.

Kowalczyk R., Prasa lokalna w Polsce, Poznań 2000.

Kowalczyk R., Wielkopolskie czasopiśmiennictwo okresu zaboru pruskiego $w$ walce o tożsamość narodowa i regionalną. Szkice prasoznawczo-politologiczne, Poznań 2018.

Koziołek A., Działalność rynku polskiej prasy ludowej dla środowisk wiejskich w zaborze pruskim, „Wieś i Rolnictwo”, 2019, no. 2, p. 131-145.

Kucharczyk G., Dlugi kulturkampf. Pruskie i niemieckie wojny kulturowe przeciw Polsce w latach 1795-1918, Warszawa 2021.

Prasa polska w latach 1661-1864, ed. J. Łojek Warszawa 1976.

Syska H., Od „Kmiotka” do „Zarania”. Z historii prasy ludowej, Warszawa 1949.

Trzeciakowski L., Pod pruskim zaborem 1850-1918, Warszawa 1973.

Turowska-Bar I., Polskie czasopisma o wsi i dla wsi, Warszawa 1963.

"Wielkopolanin" 1848-1850. 